\title{
KEWAJIBAN PEMERINTAH ATAS HAK IMBALAN JASA PELAYANAN KESEHATAN DOKTER INTERNSIP
}

\author{
Dzulqarnain Andira ${ }^{1}$, Mokhamad Kohoirul Huda ${ }^{2}$, Sulaksono $^{3}$ \\ ${ }^{1}$ Program Studi Hukum Kesehatan, Universitas Hang Tuah, Jalan Arief Rahman Hakim No150, Kota Surabaya, 60117 \\ E-mail:dira579@gmail.com \\ ${ }^{2}$ Program Studi Ilmu Hukum, Universitas Hang Tuah, Jalan Arief Rahman Hakim No150, Kota Surabaya, 60117 \\ E-mail: emka.huda@hangtuah.ac.id \\ ${ }^{3}$ Program Studi Ilmu Hukum, Universitas Hang Tuah, Jalan Arief Rahman Hakim No150, Kota Surabaya, 60117 \\ E-mail: sonkop7@yahoo.co.id
}

\begin{abstract}
This Study analyzed the government obligation for the rights of medical service reward for internship doctor at wahana internsip. The aim of this research is to know the status of an internship doctor in accordance with statutory regulations, as well as the government's responsibility for medical service reward of an internship doctor at wahana internsip. The absence of laws and regulations that regulate the rights of an internship doctor regarding compensation or reward for services from medical services performed at wahana internsip or a place where the internship doctor is in charge of providing health services. The approachment method of this research is statutory, conceptual, and comparative. The collecting method for legal materials is done by editing, classifying, and organizing. The data analysis was done qualitively. The result of this study is the status of internship doctor is a doctor that already has competencies as a medical practitioner that has been approved by Indonesian Doctor Colegium (KDI), and the intern has full responsibility for medical service at the internship place. The Government is responsible for medical service reward of internship doctor.
\end{abstract}

Keywords - : government; responsibility; medical service fee; internship

\section{PENDAHULUAN}

Hak pada hakikatnya merupakan hubungan antara subyek hukum dengan obyek hukum atau subyek hukum dengan obyek hukum dengan subyek hukum lain yang dilindungi oleh hukum dan menimbulkan kewajiban. Hak itu sah karena dilindungi oleh sistem hukum". 1

Pemerintah sebagai penyelenggara negara haruslah memperhatikan secara seksama terkait setiap kewajiban yang diembannya. Mengingat bahwa salah satu atribut hukum yang dimiliki oleh negara dalam rangka melaksanakan kewajibankewajiban konstitusional untuk warga negaranya adalah dijamin dan dilindungi oleh konstitusi dan peraturan perundangundangan yang berlaku di Indonesia, dan kewajiban negara tersebut disisi lain adalah hak yang dimiliki oleh warga negara (rakyat Indonesia). ${ }^{2}$ Hal ini penting, karena bila ada aturan yang tidak adil, terutama dari aspek kewajiban pemerintah, maka akan dapat menimbulkan kerugian bagi warga negara.

Dokter merupakan salah satu komponen warga Negara yang hak dan kewajibannya telah diatur dalam peraturan perundang-undangan. Hak dan kewajiban dokter telah diatur pada Undang Undang Republik Indonesia Nomer 29 tahun 2004 tentang Praktik Kedokteran. Sebagaimana tercantum pada pasal 50 Undang Undang Republik Indonesia No. 29 tahun 2004 tentang Praktik Kedokteran yang setelah ini penulis sebut dengan "UUPK", yang mengatur hak dokter, bahwa salah satu hak dokter yang diatur dalam UUPK pasal 50 tersebut adalah menerima imbalan jasa. Begitu pula sebaliknya, pasien sebagai penerima jasa pelayanan kesehatan, memiliki kewajiban untuk memberikan imbalan jasa atas pelayanan yang diterima, berdasarkan pasal 53. Dokter yang dimaksud dalam UUPK ini pun sudah dijelaskan pada pasal 1, "Dokter dan dokter gigi adalah dokter, dokter spesialis, dokter gigi, dan dokter gigi spesialis lulusan pendidikan kedokteran atau kedokteran gigi baik

\footnotetext{
${ }^{1}$ Sudikno Mertokusumo, Mengenal Hukum, Penerbit: Universitas Atma Jaya Yogyakarta, Yogyakarta, 2010 , h. 161.

${ }^{2}$ Naya Amin Zaini, Politik Hukum dan HAM, Jurnal Panorama Hukum, No. 2 Volume 1, 2016 h. 2.
} 
Website : http://yustisia.unmermadiun.ac.id/index.php/yustisia

di dalam maupun di luar negeri yang diakui oleh Pemerintah Republik Indonesia sesuai dengan peraturan perundangundangan". 3

Pemerintah telah mengatur ketentuan mengenai dokter internsip. Berdasarkan Peraturan Menteri Kesehatan No.39 tahun 2017 yang selanjutnya akan ditulis dengan "Permenkes No. 39 tahun 2017" tentang Penyelenggaraan Program Internsip Dokter dan Dokter Gigi Indonesia, pengertian internsip adalah "Internsip adalah proses pemantapan mutu profesi dokter dan dokter gigi untuk menerapkan kompetensi yang diperoleh selama pendidikan, secara terintegrasi, komprehensif, mandiri, serta menggunakan pendekatan kedokteran keluarga, dalam rangka pemahiran dan penyelarasan antara hasil pendidikan dengan praktik di lapangan". Permenkes No. 39 tahun 2017 tersebut juga menyebutkan bahwa dokter internsip sebagai peserta Program Internship Dokter Indonesia adalah dokter yang sudah teregistrasi secara legal, dan memiliki surat ijin praktik, dan bertanggung jawab penuh atas pelayanan kesehatan yang dilakukannya selama tindakannya menaati standar profesi kedokteran dan standar prosedur rumah sakit/puskesmas pada wahana internsip tempat dokter internsip tersebut bertugas, halhal tersebut tercantum pada pasal 1 ayat 2 , pasal 1 ayat 3 , pasal 11 ayat 1 .

Dapat disimpulkan bahwa dokter internsip adalah dokter yang telah diakui secara hukum akan kompetensinya sebagai dokter, dan memiliki ijin untuk melakukan prkatek kedokteran, dan bertanggung jawab penuh atas tindakan praktik kedokteran yang dilakukannya yang hanya terbatas pada tempat atau wahana internsip tempat dokter tersebut ditugaskan, sehingga sepatutnya pula dokter internsip mendapatkan hak nya sebagai dokter pada umumnya di tempat dia ditugaskan, atau di wahana internsipnya, salah satunya adalah hak atas imbalan jasa dokter internsip tersebut.

Belum ada kejelasan terkait kemana dana jasa pelayanan kesehatan yang dilakukan dokter internsip diberikan. Khususnya pada Permenkes No. 39 tahun 2017 pasal 11 yang belum mengatur hak dokter internsip tentang imbalan jasa dari pelayanan kesehatan yang dilakukannya. Hal tersebut mendorong peneliti untuk meneliti lebih lanjut mengenai Tanggung Jawab Pemerintah atas Hak Jasa Pelayanan Kesehatan Dokter Internsip di Wahana Internsip.

\section{ARumusan Masalah}

Berdasarkan latar belakang yang telah diuraikan di atas maka permasalahan dalam penelitian ini adalah;

1. Bagaimana status dokter internsip sesuai peraturan perundang-undangan?

2. Bagaimana tanggung jawab pemerintah atas imbalan jasa pelayanan kesehatan dokter intern sip di wahana internsip?

\section{Tujuan Penelitian}

1. Untuk mengetahui status dokter internsip sesuai peraturan perundang-undangan.

2. Untuk mengetahui tanggung jawab pemerintah atas imbalan jasa pelayanan kesehatan dokter internsip di wahana internsip.

\section{METODE PENELITIAN}

\section{A. Pendekatan Masalah}

Analisa Bahan Hukum Pendekatan yang digunakan dalam penelitian ini adalah pendekatan perundang-undangan yaitu pendekatan yang mengkaji tentang peraturan perundang-undangana dan kesesuaian antara satu undang-undang dengan undang-undang yang lain, pendekatan konseptual serta pendekatan perbandingan

\section{B. Bahan Hukum}

1. Sumber bahan hukum primer, yaitu bahan hukum yang bersifat mengikat diantaranya adalah:

a. Undang-Undang Nomor 29 Tahun 2004 tentang Praktik Kedokteran.

b. Peraturan Menteri Kesehatan No.39 tahun 2017 tentang Penyelenggaraan Program Internsip Dokter dan Dokter Gigi Indonesia

c. Undang Undang Republik Indonesia Nomor 20 Tahun 2013 tentang Pendidikan Kedokteran

d. Peraturan Menteri Kesehatan Nomor 4 Tahun 2018 tentang Kewajiban Rumah Sakit dan Kewajiban Pasien

\section{${ }^{3}$ Ibid.}


Website : http://yustisia.unmermadiun.ac.id/index.php/yustisia

e. Peraturan Menteri Kesehatan Nomor 28 Tahun 2014 tentang Pedoman Pelaksanaan Program Jaminan Kesehatan Nasional

f. Permenkes No. 27 tahun 2014 tentang Petunjuk Teknis Sistem Indonesia Case Base Groups (INA-CBGs)

g. Peraturan Menteri Kesehatan Nomor 19 Tahun 2014 tentang Penggunaan Dana Kapitasi Jaminan Kesehatan Nasional Untuk Jasa Pelayanan Kesehatan dan Dukungan Biaya Operasional pada Fasilitas Kesehatan Tingkat Pertama Milik Pemerintah Daerah.

i. Undang Undang Republik Indonesia Nomor 30 Tahun 2014 tentang Administrasi Pemerintahan

j. Undang Undang Nomor 36 tahun 2009 tentang Kesehatan

k. Peraturan Pemerintah Republik Indonesia Nomor 67 Tahun 2019 tentang Pengelolaan Tenaga Kesehatan Tenaga Kesehatan

1. Undang Undang Nomor 36 tahun 2014 tentang tentang kesehatan

m. Peraturan Menteri Kesehatan Nomor 1199 tahun 2004 tentang pedoman pengadaan tenaga kesehatan dengan perjanjian kerja di sarana kesehatan milik pemerintah

n. Undang-Undang Nomor 12 Tahun 2011 tentang Pembentukan Peraturan Perundang-undangan

o. Keputusan Menteri Kesehatan Republik Indonesia Nomor HK.02.02/MENKES/243/2016 tentang Biaya Hidup Dokter Internsip dan Honor Dokter pendamping Program Internsip Dokter Indonesia

2. Sumber bahan hukum sekunder, yaitu bahan hukum yang memberikan petunjuk serta penjelasan terhadap bahan hukum primer yang terdiri dari buku, literature, artikel, makalah, artikel, hasil penelitian dan karya ilmiah yang berhubungan dengan penlitian ini.

\section{Metode Pengumpulan Bahan Hukum}

Langkah-langkah pengumpulan bahan hukum meliputi, membaca, mempelajari, mengutip, membandingkan dan menghubungkan bahan bahan hukum dari perundang-undangan dan literature sehingga menjadi satu kesatuan untuk kemudahan dalam pengolahan bahan hukum, tahapan tahapan yang dilakukan adalah:

a. Editing, yaitu melakukan pengecekan terhadap bahan hukum secara teliti sehingga tidak terjadi kesalahan pada data yang telah dihimpun.

b. Klasifikasi, yaitu data yang telah dikumpulkan, akan dikelompokkan berdasarkan pokok bahasan masing masing, agar tidak terjadi kesalahan dalam pengelompokan data.

c. Organizing, yaitu bahan hukum yang sudah selesai dikelompokkan, diurutkan, sehingga bahan hukum tersusun secara teratur dan sistematis.

\section{Analisa Bahan Hokum}

Bahan hukum akan dianalisa secara kualitatif. Analisis itu dilakukan dengan menggambarkan kata-kata atau kalimat yang dipisahkan menurut kategori untuk mendapatkan suatu kesimpulan. ${ }^{4}$ Menganalisa dengan mendeskripsikan data menggunakan kata-kata dan digunakan untuk menafsirkan dan menginterpretasikan data hasil lisan ataupun tertulis dari orang tertentu dan perilaku yang diamati. ${ }^{5}$

\section{PEMBAHASAN}

\section{A. Status Dokter Internsip Dalam Peraturan Perundang-Undangan Di Indonesia}

\section{Dokter Intersip dalam Peraturan Perundang-Undangan}

Dokter adalah dokter atau dokter spesialis lulusan pendidikan kedokteran baik di dalam maupun di luar negeri yang diakui oleh Pemerintah Republik Indonesia sesuai dengan peraturan perundang-undangan, hal ini tercantum pada pasal 53 UUPK. Sedangkan berdasarkan pasal 1 ayat 1 Permenkes No. 39 tahun 2017 tentang Penyelenggaraan Program Internsip Dokter Indonesia, pengertian internsip adalah proses pemantapan mutu profesi dokter untuk menerapkan kompetensi yang diperoleh selama pendidikan, secara terintegrasi, komprehensif, mandiri, serta menggunakan pendekatan kedokteran keluarga, dalam rangka pemahiran dan penyelarasan antara hasil pendidikan dengan praktik di lapangan. Sehingga pengertian Dokter Internsip adalah Dokter lulusan Pendidikan Kedokteran yang sedang menjalani Proses pemantapan mutu profesi

Pendidikan yang telah ditempuh oleh dokter internsip, mengacu pada pasal 7 ayat 7 Undang Undang Republik Indonesia Nomor 20 Tahun 2013 tentang Pendidikan Kedokteran yang selanjutnya disebut "UU Pendidikan Kedokteran" menyebutkan bahwa pendidikan profesi dokter dilanjutkan dengan program internsip, dimana untuk menyelesaikan

\footnotetext{
${ }^{4}$ Suharsimi arikunto, Prosedur penelitian, Rineka Cipta, Jakarta, 2019, h. 30.

${ }^{5}$ Lexy j moleong, Metodologi penelitian kualitatif, PT remaja rosdakarya, Bandung, 2017 , h. 41.
} 
pendidikan profesi dokter haruslah menempuh pendidikan akademik dahulu. Maka pendidikan yang telah ditempuh oleh dokter internsip adalah pendidikan akademik dan profesi kedokteran. Dokter internsip telah memiliki kompetensi sebagai dokter yang diterbitkan oleh konsil kedokteran Indonesia yang selanjutnya disingkat menjadi "KKI", telah diatur oleh KKI pada Kebijakan Penerbitan Sertifikat Kompetensi Dokter dan Dokter Spesialis. ${ }^{6}$

Untuk menjadi seorang dokter di Indonesia berdasarkan UU Pendidikan Kedokteran, seorang mahasiswa kedokteran harus melewati beberapa jenjang pendidikan berupa pendidikan akademik, pendidikan profesi dan program internsip. Berdasarkan Pasal 1 angka 2 Pendidikan akademik adalah pendidikan tinggi program sarjana dan/atau program pascasarjana kedokterandan kedokteran gigi yang diarahkan terutama pada penguasaan ilmu kedokteran. Pasal 1 angka 3 Pendidikan profesi adalah pendidikan kedokteran yang dilaksanakan melalui proses belajar mengajar dalam bentuk pembelajaran klinik dan pembelajaran komunitas yang menggunakan berbagai bentuk dan tingkat pelayanan kesehatan nyata yang memenuhi persyaratan sebagai tempat praktik kedokteran. ${ }^{7}$

Berbagai negara menerapkan program internsip untuk dokter, antara lain di Australia dan Inggris, pada negara tersebut setelah melalui sekolah kedokteran, diwajibkan mengikuti internsip. Di Australia, Internsip berlangsung selama 1 tahun, apabila dalam waktu satu tahun telah selesai menjalani masa internsip dengan hasil yang memuaskan, maka akan diberikan registrasi medis umum oleh Medical Board Assosiation (MBA). Sementara di negara Inggris setelah menjalani sekolah kedokteran, diwajibkan melalui 1 tahun masa internsip yang disebut dengan foundation year 1 training (F1), setelah menyelesaikan F1, registrasi penuh diberikan oleh General Medical Council (GMC). Sementara di negara Belanda, dokter diberikan registrasi penuh setelah menyelesaikan sekolah kedokterannya, tanpa harus melalui masa internsip. ${ }^{8}$

2. Hak Dan Tanggung Jawab Dokter Internsip

STR internsip, STR sendiri adalah singkatan dari Surat Tanda Registrasi, Registrasi yang dimaksud disini adalah pencatatan resmi terhadap dokter yang telah memiliki kualifikasi tertentu lainnya serta diakui secara hukum untuk melakukan tindakan profesinya. Sementara STR internsip adalah Bukti tertulis yang diberikan oleh Konsil Kedokteran Indonesia kepada dokter yang telah diregistrasi untuk mengikuti kegiatan internsip. ${ }^{9}$

SIP adalah singkatan dari surat ijin praktik, yang memiliki arti bukti tertulis yang diberikan pemerintah kepada dokter yang akan menjalankan praktik kedokteran setelah memenuhi persyaratan. Sementara Surat lzin Praktik Internsip yang selanjutnya disebut SIP Internsip adalah bukti tertulis yang diberikan Pemerintah Daerah kepada dokter yang akan menjalankan praktik kedokteran selama Internsip setelah memiliki STR Internsip. Setiap peserta internsip wajib mengurus dan memiliki Surat Izin Praktek dokter untuk setiap wahana yang ditempati peserta.

Surat Tanda Registrasi Untuk Kewenangan Internsip, yang selanjutnya disingkat STR Internsip adalah bukti tertulis yang diberikan oleh Konsil Kedokteran Indonesia kepada dokter yang akan menjalankan praktik kedokteran selama Internsip. Surat tanda registrasi dokter adalah bukti tertulis yang diberikan oleh Konsil Kedokteran Indonesia kepada dokter yang telah diregistrasi. Sementara Registrasi adalah pencatatan resmi terhadap dokter yang telah memiliki sertifikat kompetensi dan telah mempunyai kualifikasi tertentu lainnya serta diakui secara hukum untuk melakukan tindakan profesinya.

Secara singkat, STR dokter dan dokter internsip hanya memiliki perbedaan pada masa berlaku yakni pada STR dokter internsip memiliki masa berlaku hingga masa internsip, sementara STR dokter berlaku hingga 5 tahun sejak tanggal ditetapkan dan berakhir sesuai dengan tanggal kelahiran dokter yang bersangkutan. Persamaan dari kedua STR tersebut antara lain keduanya diterbitkan oleh Konsil Kedokteran Indonesia, keduanya adalah pencatatan resmi terhadap dokter yang telah memiliki kualifikasi tertentu lainnya serta diakui secara hukum untuk melakukan tindakan profesinya.

Sesuai dengan UUPK hak dokter antara lain memperoleh perlindungan hukum sepanjang melaksanakan tugas sesuai dengan standar profesi dan standar prosedur operasional, memberikan pelayanan medis menurut standar profesi dan standar prosedur operasional, memperoleh informasi yang lengkap dan jujur dari pasien atau keluarganya; dan menerima imbalan jasa.

Sedangkan kewajibannya adalah memberikan pelayanan medis sesuai dengan standar profesi dan standar prosedur operasional serta kebutuhan medis pasien; merujuk pasien ke dokter lain yang mempunyai keahlian atau kemampuan yang lebih baik, apabila tidak mampu melakukan suatu pemeriksaan atau pengobatan; merahasiakan segala sesuatu yang diketahuinya tentang pasien, bahkan juga setelah pasien itu meninggal dunia; melakukan pertolongan darurat atas dasar perikemanusiaan, kecuali bila ia yakin ada orang lain yang bertugas dan mampu melakukannya; dan menambah ilmu pengetahuan dan mengikuti perkembangan ilmu kedokteran.

${ }^{6}$ Aida SD Hoemardani, Kebijakan Penerbitan Sertifikat Kompetensi Dokter dan Dokter Spesialis, Konsil Kedokteran Indonesia, Jakarta, 2020, h. 4.

${ }^{7}$ Rozi Kodarusman W, Perlindungan Hukum terhadap Dokter Internsip dalam Pelayanan Kesehatan di Wahana Internsip (Rumah Sakit dan Puskesmas) Wilayah Lampung, Repository UGM, Yogyakarta, 2019, h. 4.

${ }^{8}$ Margot M, Weggemans et al, The postgraduate medical education pathway: an international comparison, GMS Journal, No 34, Volume 15, 2017, h. 5.

${ }^{9}$ Departemen Kesehatan RI, Pedoman Pelaksanaan Internsip Dokter Indonesia, Jakarta, 2009, h. 2 
Sementara Dokter Internsip memiliki hak yang telah diatur dalam buku pedoman peserta program internsip dokter Indonesia sebagai berikut:

1. Mendapat bantuan biaya hidup dan penggantian transportasi bagi dokter yang mengikuti program internsip ikatan dinas;

2. Memilih fasilitas pelayanan kesehatan yang telah ditetapkan oleh menteri bagi dokter yang mengikuti program internsip mandiri;

3. Mendapat perlindungan hukum dari pemerintah selama menjalankan program internsip sesuai dengan standar profesi

4. Mendapatkan cuti selama sepuluh (10) hari kerja yang tidak dilaksanakan secara berturut-berturut untuk menjalankan upacara pernikahan, menghadiri upaya kematian orang tua/ saudara kandung/ kakek/nenek/ suami/ istri/ anak, menjalankan tugas negara, menjalani rawat inap karena sakit yang dialami.

5. Mendapat izin untuk tidak melaksanakan program internsip, diluar hak cuti sebagaimana dimaksud pada butir 4 dan wajib mengganti sebanyak hari yang ditinggalkan;

6. Mendapatkan hak lainnya sesuai dengan ketentuan peraturan perundang-undangan. ${ }^{10}$

Kemudian terkait kewajiban dari dokter Internsip yang juga telah diatur dalam buku pedoman peserta program internsip dokter Indonesia yakni Setiap dokter, peserta internsip mempunyai kewajiban yaitu:

1. Bekerja sesuai dengan standar kompetensi, standar pelayanan dan standar profesi medik;

2. Mengintegrasikan pengetahuan, keterampilan, dan sikap yang diperoleh selama pendidikan dan mengaplikasikannya dalam pelayanan kesehatan;

3. Mengembangkan keterampilan praktik kedokteran pelayanan kesehatan primer;

4. Bekerja dalam batas kewenangan hukum dan etika;

5. Berperan aktif dalam tim pelayanan kesehatan holistik, terpadu, paripurna;

6. Mematuhi ketentuan peraturan perundang-undangan. ${ }^{11}$

Berikut dapat diketahui bahwa ada beberapa persamaan serta perbedaan dari aspek hak dan kewajiban dokter dan dokter internsip persamaan yang dapat doitemui adalah mendapat perlindungan hukum dari Pemerintah selama menjalankan pelayanan sesuai dengan standar profesi, bekerja sesuai dengan standar kompetensi, standar pelayanan dan standar profesi medik; mematuhi ketentuan peraturan perundang-undangan

Begitu pula dapat diketahui terkait perbedaan yang terdapat pada hak dan kewajiban dokter dan dokter internsip hal tersebut antara lain bahwa dokter memiliki hak atas jasa pelayanan yang dilakukannya namun tidak dengan dokter internsip kemudian dokter memiliki hak untuk melakukan praktik di fasilitas kesehatan manapun sedangkan dokter internsip hanya dapat melakukan pelayanan kesehatan terbatas hanya pada wahana internsip saja.

Dengan demikian perlu diketahui status dokter internsip dengan pertama-tama memahami terkait statusnya dalam peraturan perundang-undangan bahwa dalam UUPK telah disebutkan bahwa Sertifikat kompetensi adalah surat tanda pengakuan terhadap kemampuan seorang dokter untuk menjalankan praktik kedokteran di seluruh Indonesia setelah lulus uji kompetensi yang sertifikat ini diterbitkan oleh konsil kedokteran indonesia. Konsil Kedokteran Indonesia adalah suatu badan otonom, mandiri, nonstruktural, dan bersifat independen. KKI mempunyai tugas pada Pasal 7 UUPK:

1. Melakukan registrasi dokter;

2. Mengesahkan standar pendidikan profesi dokter

3. Melakukan pembinaan terhadap penyelenggaraan praktik kedokteran yang dilaksanakan bersama lembaga terkait sesuai dengan fungsi masing-masing.

Kemudian KKI memiliki fungsi : KKI mempunyai fungsi pada Pasal 6 UUPK, yaitu fungsi pengaturan, pengesahan, penetapan, serta pembinaan dokter dan dokter gigi yang menjalankan praktik kedokteran, dalam rangka meningkatkan mutu pelayanan medis

Telah disebutkan sebelumnya bahwa dokter internsip adalah dokter yang telah memiliki kompetensi sebagai dokter umum, karena telah diakui kompetensinya oleh Konsil Kedokteran Indonesia (KKI) Surat tanda registrasi dokter adalah bukti tertulis yang diberikan oleh Konsil Kedokteran Indonesia kepada dokter yang telah diregistrasi sementara dokter internsip telah memiliki str internsip yakni Surat Tanda Registrasi Untuk Kewenangan Internsip, yang selanjutnya disingkat STR praktik adalah bukti tertulis yang diberikan pemerintah kepada dokter yang akan menjalankan praktik kedokteran setelah memenuhi persyaratan. Sementara dokter internsip juga telah memiliki SIP Internsip yakni Surat lzin Praktik Internsip yang merupakan bukti tertulis yang diberikan Pemerintah Daerah kepada yang akan menjalankan praktik kedokteran adalah bukti tertulis yang diberikan oleh Konsil Kedokteran Indonesia kepada dokter yang akan menjalankan praktik kedokteran selama Internsip. sementara SIP sendiri Surat izin selama Internsip setelah memiliki STR Internsip.

\footnotetext{
${ }^{10}$ Departemen Kesehatan RI, Pedoman Pelaksanaan Internsip Dokter Indonesia, Jakarta, 2009, h.9

${ }^{11}$ Departemen Kesehatan RI, Pedoman Pelaksanaan Internsip Dokter Indonesia, Jakarta, 2009, h.9.
} 
Website : http://yustisia.unmermadiun.ac.id/index.php/yustisia

Dengan demikian dapat diketahui bahwa status dokter internsip adalah dokter yang telah memiliki kompetensi sebagai dokter umum, karena telah diakui kompetensinya oleh Konsil Kedokteran Indonesia, dan telah memiliki STR dan SIP layaknya dokter pada umumnya hanya saja kewenangan dan tanggung jawabnya hanya terbatas pada wahana internsipnya saja

\section{B. Tanggung Jawab Pemerintah Atas Imbalan Jasa Pelayanan Kesehatan Dokter Internsip Di Wahana Internsip}

1. Imbalan Jasa Pelayanan Kesehatan

Pada Undang-Undang Kesehatan disebutkan bahwa Upaya kesehatan adalah setiap kegiatan dan/atau serangkaian kegiatan yang dilakukan secara terpadu, terintregasi dan berkesinambungan untuk memelihara dan meningkatkan derajat kesehatan masyarakat dalam bentuk pencegahan penyakit, peningkatan kesehatan, pengobatan penyakit, dan pemulihan kesehatan oleh pemerintah dan/atau masyarakat.

Terkait imbalan jasa pelayanan kesehatan untuk tenaga kesehatan sendiri telah diatur dalam system perundangundangan sebagaimana tercantum pada Pasal 27 ayat 1 Undang Undang Nomor 36 tahun 2009 tentang Kesehatan Tenaga kesehatan berhak mendapatkan imbalan dan pelindungan hukum dalam melaksanakan tugas sesuai dengan profesinya sementara Tenaga kesehatan itu sendiri adalah setiap orang yang mengabdikan diri dalam bidang kesehatan serta memiliki pengetahuan dan/atau keterampilan melalui pendidikan di bidang kesehatan yang untuk jenis tertentu memerlukan kewenangan untuk melakukan upaya kesehatan dan telah diatur pula dalam Pasal 87 ayat 1 Peraturan Pemerintah Republik Indonesia Nomor 67 Tahun 2019 tentang Pengelolaan Tenaga Kesehatan Tenaga Kesehatan dalam menjalankan praktik berhak: memperoleh pelindungan hukum; dan memperoleh imbalan

Pada pasal 57 ayat 3 Undang Undang Nomor 36 tahun 2014 tentang tenaga kesehatan menyebutkan bahwa tenaga kesehatan berhak menerima imbalan jasa kemudian pada peraturan menteri kesehatan nomor 1199 tahun 2004 tentang pedoman pengadaan tenaga kesehatan dengan perjanjian kerja di sarana kesehatan milik pemerintah juga menyebutkan salah satu hak dari tenaga kesehatan salah satunya adalah memperoleh insentif berupa jasa medik. Hak terkait imbalan jasa dokter secara spesifik juga telah diatur pada UUPK pada pasal 50 bahwa salah satu hak dokter adalah menerima imbalan jasa

Pada fasilitas kesehatan tingkat lanjutan (FKTRL) Pembayaran pelayanan kesehatan dengan menggunakan sistem INA CBGs. INA CBGs sendiri, berdasarkan Peraturan menteri kesehatan Nomor 27 tahun 2014 tentang Petunjuk Teknis Sistem Indonesia Case Base Groups (INA-CBGs) menyebutkan bahwa klaim pembayaran terintegrasi dari mulai manajemen rumah sakit, dokter, dan seluruh karyawan rumah sakit.

Pada Puskesmas pada pasal 3 ayat 1 Peraturan Menteri Kesehatan Nomor 19 Tahun 2014 tentang Penggunaan Dana Kapitasi Jaminan Kesehatan Nasional Untuk Jasa Pelayanan Kesehatan dan Dukungan Biaya Operasional pada Fasilitas Kesehatan Tingkat Pertama Milik Pemerintah Daerah (Berita Negara Republik Indonesia Tahun 2014 Nomor 589) menyebutkan bahwa Dana Kapitasi yang diterima oleh FKTP dari Badan Penyelenggara Jaminan Sosial Kesehatan dimanfaatkan seluruhnya untuk: a. pembayaran jasa pelayanan kesehatan; dan b. dukungan biaya operasional pelayanan kesehatan.

Pada pasal 1 ayat 3 disebutkan pengertian dana kapitasi, yakni dana kapitasi adalah besaran pembayaran per-bulan yang dibayar dimuka kepada FKTP berdasarkan jumlah peserta yang terdaftar tanpa memperhitungkan jenis dan jumlah pelayanan kesehatan yang diberikan.

Namun hak dokter internsip atas imbalan jasa pelayanan kesehatan yang dilakukannya belum diatur secara spesifik pada peraturan tentang penyelenggaraan program internsip dokter Indonesia hingga pada peraturan pedoman pelaksanaan program internsip belum diatur mengenai hak atas imabalan jasa pelayanan kesehatan dokter internsip atau kemana dana imbalan jasa dokter internsip itu disalurkan Peraturan teknis di rumah sakit terkait imbalan jasa pelayanan kesehatan belum diatur dalam pedoman pelaksanaan internsip dokter Indonesia dari Departemen Kesehatan Republik Indonesia Badan PPSDM Kesehatan pada tahun 2009 baik pada buku pedoman pelaksanaan, peserta, pendamping, maupun wahana.

Keputusan Menteri Kesehatan Republik Indonesia Nomor HK.02.02/MENKES/243/2016 tentang Biaya Hidup Dokter Internsip dan Honor Dokter pendamping Program Internsip Dokter Indonesia juga tidak mengatur terkait imbalan jasa pelayanan kesehatan dokter internsip

Sementara di Negara lain seperti Inggris, sebagai seorang dokter internsip atau yang disana disebut Foundation Year 1 doctor (F1), dokter tersebut akan mendapatkan gaji pokok sebesar £28,243, atau bila di rupiahkan senilai dengan Rp. 546.379.936 hingga Rp 746.067.139 per tahun, ditambah gaji jam kerja yang lebih dari 40 jam per pekan, ditambah peningkatan gaji 37\% untuk jam kerja malam, diperbolehkan bekerja pada akhir pekan diluar program F1, tambahan biaya bila dokter bersedia siaga melalui telpon, dan tambahan potensi pembayaran premia lainnya. ${ }^{12}$ Sehingga perlu dilakukan peninjauan ulang terhadap besaran gaji pokok dari dokter internsip di Indonesia.

2. Tanggung Jawab Pemerintah dalam pemenuhan Hak Imbalan Jasa Pelayanan Kesehatan Dokter Internsip

${ }^{12}$ National Health Center, Pay for Doctors. Healthcareers NHS UK, London, 2020, h. 1. 
Pemerintah sebagai pelayan rakyat haruslah memenuhi hak hak konstitusional seluruh warga negara republik Indonesia karena hal tersebut merupakan kewajiban negara untuk memenuhinya sesuai dengan amanat UUD 1945 Fungsi dari pemerintahan adalah melaksanakan administrasi Pemerintahan yang meliputi tugas pengaturan, pelayanan, pembangunan, pemberdayaan dan perlindungan, hal ini tercantum pada Undang Undang Republik Indonesia Nomor 30 Tahun 2014 tentang Administrasi Pemerintahan Pasal 1 ayat 2 sehingga hak dari warganegara harus dilindungi oleh pemerintah sehingga norma ini dapat menjadi acuan untu pemenuhan dan perlindungan hak warga negara termasuk dokter internsip dimana Sementara pada pasal 48 dan pasal 51 Undang-Undang nomor 44 tahun 2009 tentang Rumah Sakit, tentang tanggung jawab pemerintah terhadap rumah sakit daerah menyebutkan bahwa pembiayaan rumah sakit salah satunya bersumber dari pemerintah dan pemerintah daerah Pada pasal 51 Undang-Undang rumah sakit juga disebutkan bahwa pendapatan rumah sakit publik dikelola pemerintah dan pemerintah daerah digunakan seluruhnya secara langsung untuk biaya operasional rumah sakit dan tidak dapat dijadikan pendapatan negara atau pemerintah daerah Pada Peraturan menteri kesehatan Nomor 28 Tahun 2014 tentang Pedoman Pelaksanaan Program Jaminan Kesehatan Nasional, pada bab 5 tentang pendanaan, menyebutkan bahwa pemerintah berkoordinasi dengan dinas kesehatan daerah terkait pembagian jasa pelayanan tenaga kesehatan pada Fasilitas Kesehatan Tingkat Pertama (FKTP) yang salah satunya adalah pusat kesehatan masyarakat (puskesmas). pada pasal 3 ayat 1 Peraturan Menteri Kesehatan Nomor 19 Tahun 2014 tentang Penggunaan Dana Kapitasi Jaminan Kesehatan Nasional Untuk Jasa Pelayanan Kesehatan dan Dukungan Biaya Operasional pada Fasilitas Kesehatan Tingkat Pertama Milik Pemerintah Daerah (Berita Negara Republik Indonesia Tahun 2014 Nomor 589) menyebutkan bahwa Dana Kapitasi yang diterima oleh FKTP dari Badan Penyelenggara Jaminan Sosial Kesehatan dimanfaatkan seluruhnya untuk: a. pembayaran jasa pelayanan kesehatan; dan b. dukungan biaya operasional pelayanan kesehatan.

Sebagai sumber pembiayaan rumah sakit daerah pemerintah secara otomatis wajib memberikan imbalan jasa kepada pekerja yang bertugas di rumah sakit daerah berdasarkan peraturan yang Pada era BPJS Kewajiban Rumah Sakit telah diatur salah satunya pada Permenkes No 4 tahun 2018 pasal 23 ayat 3 butir 1 yakni rumah sakit wajib memberikan imbalan jasa yang adil dan layak sesuai dengan beban kerja, tanggung jawab, dan risiko pekerjaan dari petugas yang bekerja di rumah sakit. Sementara pemerintah juga memiliki kewajiban untuk berkoordinasi dengan dinas kesehatan daerah terkait imbalan jasa pelayanan kesehatan hal tersebut terdapat Pada Permenkes No. 28 Tahun 2014 tentang Pedoman Pelaksanaan Program Jaminan Kesehatan Nasional, pada bab 5 tentang pendanaan, menyebutkan bahwa pemerintah berkoordinasi dengan dinas kesehatan daerah terkait pembagian jasa pelayanan tenaga kesehatan pada Fasilitas Kesehatan Tingkat Pertama (FKTP) yang salah satunya adalah pusat kesehatan masyarakat (puskesmas).

Dapat diketahui bahwa dalam pasal 28D ayat 1 UUD 1945 Hak atas pengakuan, jaminan, perlindungan, dan kepastian hukum yang adil serta perlakuan yang sama di depan hukum. dimana pemerintah memiliki kewajiban dan tanggung jawab untuk memberikan perlindungan serta kepastian hukum yang adil, diperlukan kepastian hukum serta keadlian terhadap dokter internsip dalam pemenuhan haknya atas jasa pelayanan kesehatan, mengingat telah diatur pula tanggung jawab pemerintah dalam memenuhi pembiayaan rumah sakit daerah serta puskesmas yang merupakan wahana internsip pada Undang-Undang Rumah Sakit, pada pasal 48 dan pasal 51 tentang tanggung jawab pemerintah terhadap rumah sakit daerah menyebutkan bahwa pembiayaan rumah sakit salah satunya bersumber dari pemerintah dan pemerintah daerah kemudian pada Permenkes No. 28 Tahun 2014 tentang Pedoman Pelaksanaan Program Jaminan Kesehatan Nasional, pada bab 5 tentang pendanaan, menyebutkan bahwa pemerintah berkoordinasi dengan dinas kesehatan daerah terkait pembagian jasa pelayanan tenaga kesehatan pada Fasilitas Kesehatan Tingkat Pertama (FKTP) yang salah satunya adalah pusat kesehatan masyarakat (puskesmas). Sementara dari aspek kewajiban pemerintah dalam memenuhi hak jasa pelayanan kesehatan terhadap dokter internsip pun dapat dilihat dalam Undang undang tenaga kesehatan dan Undang undang kedokteran dimana tercantum pada UU Kesehatan Pasal 27 (1) Tenaga kesehatan berhak mendapatkan imbalan dan pelindungan hukum dalam melaksanakan tugas sesuai dengan profesinya serta pada Undang Undang Praktik Kedokteran adalah merupakan hak dokter menerima imbalan jasa pelayanan kesehatan yang dilakukannya Telah disebutkan sebelumnya bahwa rumah sakit daerah dan puskesmas adalah termasuk wahana internsip dimana dokter Internsip melakukan tugasnya kemudian telah diatur dalam SK menteri kesehatan terkait hak dokter internsip atas bantuan biaya Hidup kemudian hak nya juga telah diatur dalam pedoman pelaksanaan program internsip sehingga pemerintah memiliki kewajiban memenuhi hak dari dokter internsip tersebut namun kewajiban pemerintah atas pemenuhan hak atas imbalan jasa pelayanan kesehatan dokter internsip belum diatur dengan jelas pada peraturan perundang-undangan.

\section{PENUTUP}

\section{A Kesimpulan}

Berdasarkan hasil Penelitian dan Pembahasan, maka dapat disimpulkan sebagai berikut:

1. Status dokter internsip dalam peraturan perundang-undangan telah diatur dalam UUPK yang mengatur bahwa sertifikat kompetensi adalah surat tanda pengakuan terhadap kemampuan seorang dokter untuk menjalankan praktik kedokteran di seluruh Indonesia setelah lulus uji kompetensi yang sertifikat ini diterbitkan oleh konsil kedokteran Indonesia dimana dokter internsip telah memiliki sertifikat kompetensi tersebut sehingga telah sah secara hukum terkait kompetensinya 
sebagai dokter dan registrasi serta ijin yang telah dimiliki oleh dokter internsip yang berlaku terbatas pada waktu dan tempat tugas internsip dilaksanakan

2. Pemerintah memiliki kewajiban dan tanggung jawab untuk memberikan perlindungan serta kepastian hukum yang adil. diperlukan kepastian hukum serta keadlian terhadap dokter internsip dalam pemenuhan haknya atas jasa pelayanan kesehatan, mengingat telah diatur pula tanggung jawab pemerintah dalam memenuhi pembiayaan rumah sakit daerah serta puskesmas yang merupakan wahana internsip pada pasal 48 dan pasal 51 Undang-Undang Rumah Sakit, tentang tanggung jawab pemerintah terhadap rumah sakit daerah menyebutkan bahwa pembiayaan rumah sakit salah satunya bersumber dari pemerintah dan pemerintah daerah kemudian pada Permenkes Jaminan Kesehatan Nasional, pada bab 5 tentang pendanaan, menyebutkan bahwa pemerintah berkoordinasi dengan dinas kesehatan daerah terkait pembagian jasa pelayanan tenaga kesehatan pada Fasilitas Kesehatan Tingkat Pertama (FKTP) yang salah satunya adalah pusat kesehatan masyarakat (puskesmas). Dimana rumah sakit daerah dan pusat kesehatan masyarakat merupakan wahana

B Saran internsip.

Adapun dalam penelitian ini adalah sebagai berikut:

1. Pemerintah wajib melakukan perubahan Permenkes No. 39 tahun 2017 tentang Program Internsip Dokter Indonesia dengan memasukkan pasal-pasal yang secara jelas mengatur hak imbalan jasa pelayanan kesehatan dokter internsip.

2. Pemerintah wajib memperjelas status dokter internsip dalam perundang-undangan, dikarenakan kompetensinya sebagai dokter umum yang telah diakui Konsil Kedokteran Indonesia, sehingga dalam Undang Undang Republik Indonesia Nomor 20 Tahun 2013 tentang Pendidikan Kedokteran, dokter internsip dapat dibedakan dari dokter yang masih menjalani program pendidikan kedokteran.

\section{DAFTAR PUSTAKA}

\section{A. Buku}

Sudikno Mertokusumo, Mengenal Hukum, Penerbit: Universitas Atma Jaya Yogyakarta, Yogyakarta, 2010, h. 161.

Suharsimi arikunto, Prosedur penelitian, Rineka Cipta, Jakarta, 2019, h. 30.

Lexy j moleong, Metodologi penelitian kualitatif, PT remaja rosdakarya, Bandung, 2017 , h. 41.

Departemen Kesehatan RI, Pedoman Pelaksanaan Internsip Dokter Indonesia, Jakarta, 2009, h. 2

Departemen Kesehatan RI, Pedoman Pelaksanaan Internsip Dokter Indonesia, Jakarta, 2009, h.9

\section{B. Jurnal}

Naya Amin Zaini, Politik Hukum dan HAM, Jurnal Panorama Hukum, No. 2 Volume 1, 2016 h. 2.

Aida SD Hoemardani, Kebijakan Penerbitan Sertifikat Kompetensi Dokter dan Dokter Spesialis, Konsil Kedokteran Indonesia, Jakarta, 2020, h. 4.

Rozi Kodarusman W, Perlindungan Hukum terhadap Dokter Internsip dalam Pelayanan Kesehatan di Wahana Internsip (Rumah Sakit dan Puskesmas) Wilayah Lampung, Repository UGM, Yogyakarta, 2019, h. 4.

Margot M, Weggemans et al, The postgraduate medical education pathway: an international comparison, GMS Journal, No 34, Volume 15, 2017, h. 5.

National Health Center, Pay for Doctors. Healthcareers NHS UK, London, 2020, h. 1.

\section{Peraturan perundang-undangan}

Undang-Undang Dasar 1945 tentang Hak atas pengakuan, jaminan, perlindungan, dan kepastian hukum yang adil serta perlakuan yang sama di depan hukum. pasal 28D ayat 1

Undang Undang Republik Indonesia Nomor 30 Tahun 2014 tentang Administrasi Pemerintahan

Undang-Undang Nomor 44 tahun 2009 tentang Rumah Sakit, pada pasal 48 dan pasal 51 tentang tanggung jawab pemerintah terhadap rumah sakit daerah

Undang Undang Republik Indonesia Nomor 36 tahun 2009 tentang Kesehatan Pasal 27 ayat 1

Undang Undang Republik Indonesia Nomor 36 tahun 2014 tentang Tenaga Kesehatan pasal 57

Undang Undang Republik Indonesia Nomor 20 Tahun 2013 tentang Pendidikan Kedokteran Pasal 7 ayat 7

Undang Undang Republik Indonesia Nomor 29 Tahun 2004 tentang Praktik Kedokteran, pasal 50. Lembaran Negara Republik Indonesia Tahun 2004 nomor 116 Tambahan Lembar Negara Republik Indonesia Nomor 4431.

Undang Undang Republik Indonesia Nomor 29 tahun 2004 tentang Praktik Kedokteran, pasal 53. Lembaran Negara Republik Indonesia Tahun 2004 nomor 116 Tambahan Lembar Negara Republik Indonesia Nomor 4431. 
Website : http://yustisia.unmermadiun.ac.id/index.php/yustisia

Undang Undang Republik Indonesia Nomor 29 tahun 2004 tentang Praktik Kedokteran, pasal 1. Lembaran Negara Republik Indonesia Tahun 2004 nomor 116 Tambahan Lembar Negara Republik Indonesia Nomor 4431.

Peraturan Menteri Kesehatan Nomor 39 tahun 2017 tentang Penyelenggaraan Program Internsip Dokter dan Dokter Gigi Indonesia.

Peraturan Menteri Kesehatan Nomor 28 Tahun 2014 tentang Pedoman Pelaksanaan Program Jaminan Kesehatan Nasional

Peraturan Menteri Kesehatan Nomor 27 Tahun 2014 tentang Petunjuk Teknis Sistem Indonesia Case Base Groups (INACBGs)

Peraturan Menteri Kesehatan Nomor 4 Tahun 2018 tentang Kewajiban Rumah Sakit dan Kewajiban Pasien

Undang-Undang Nomor 12 Tahun 2011 tentang Pembentukan Peraturan Perundang-undangan

Peraturan Menteri Kesehatan Nomor 1199 tahun 2004 tentang pedoman pengadaan tenaga kesehatan dengan perjanjian kerja di sarana kesehatan milik pemerintah

Keputusan Menteri Kesehatan Republik Indonesia Nomor HK.02.02/MENKES/243/2016 tentang Biaya Hidup Dokter Internsip dan Honor Dokter pendamping Program Internsip Dokter Indonesia 